\title{
AVALIAÇÃO DA EFICIÊNCIA DA LOGÍSTICA REVERSA DE EMBALAGENS VAZIAS DE AGROQUÍMICOS.
}

\section{Camila de S. Gabriel*, Karina B. Marsola, Andrea Leda R. de Oliveira. \\ Resumo}

Com a expansão do agronegócio brasileiro, se intensificou o uso de agroquímicos, tendo como consequências a crescente geração de embalagens vazias de defensivos químicos. Em 2017, o Estado do Mato Grosso foi o que mais se destacou em reciclagem de embalagens vazias de agrotóxicos, apenas este estado representou $23,55 \%$. Este projeto tem como objetivo comparar a eficiência da logística reversa de embalagens vazias entre os Estados do Mato Grosso e de São Paulo, em que há maior volume de descarte.

\section{Palavras-chave:}

Logística Reversa, Embalagens Vazias de Agroquímicos, Sustentabilidade.

\section{Introdução}

Com a expansão do agronegócio brasileiro, se intensificou o uso de agroquímicos, tendo como consequências a crescente geração de embalagens vazias de defensivos químicos.

Diante da crescente conscientização e preocupação com as inúmeras quantidades de embalagens que são descartadas de maneira irregular, em 2002 foi fundado o Instituto Nacional de Processamento de Embalagens Vazias (InpEV), que é uma entidade sem fins lucrativos que representa a indústria fabricante nas suas responsabilidades relacionadas à logística reversa das embalagens de produtos agroquímicos.

O InpEV vem se destacando e atualmente é considerado referência em logística reversa no Brasil e no mundo, este sucesso é devido ao fato de conseguir mobilizar todos os elos da cadeia, a partir da responsabilidade compartilhada. Com isso, esta pesquisa tem como objetivo comparar a eficiência da logística reversa de embalagens vazias entre os Estados do Mato Grosso e de São Paulo, em que há maior volume de descarte.

\section{Resultados e Discussão}

O programa "Campo Limpo" do InpEV atualmente possui 111 centrais cadastradas, 298 postos, 4,9 recebimentos itinerantes, 4 incineradoras e 11 recicladoras. No estado de São Paulo encontram-se 14 centrais e 37 postos, 8 recicladoras e 2 incineradoras, estando a maioria destas concentradas na região sudeste.

Entre 2016 e 2017, o Estado do Mato Grosso foi o que mais se destacou em reciclagem de embalagens vazias de agrotóxicos, apenas este estado representou $23,55 \%$ das embalagens que foram descartadas corretamente. Pelo fato de não haver nenhuma incineradora próxima a região centro-oeste, a grande maioria dos agricultores estão sendo prejudicados pela distância geográfica entre as unidades incineradoras e a propriedade rural. Em 2017 as regiões que obtiveram os maiores valores consumo de defensivos foram: Centro-oeste (Mato Grosso), Sul (Rio Grande do Sul) e Sudeste (São Paulo). Sendo os principais defensivos comercializados: herbicidas e fungicidas, representam no mercado $58,5 \%$ e $12,1 \%$ respectivamente.

Para a estimativa das quantidades de embalagens que foram usadas nos estados de São Paulo e Mato Grosso, se baseou na área plantada de cana-de-açúcar no ano de 2015, pois esta cultura segundo o (SINDIVEG, 2019), foi a segunda cultura maior consumo de defensivos, 11,7\%, e segundo (PIGNATTI, 2017) a cultura de cana utiliza em média 4,8 I/ha de agroquímicos. Com isso conseguimos estimar as quantidades de embalagens utilizadas nos 15 principais municípios produtores de cana-de-açúcar em São Paulo e Mato Grosso.

Figura 1. Estimativa das quantidades de embalagens utilizadas na cultura de cana de açúcar nos estados do Mato Grosso e São Paulo,.
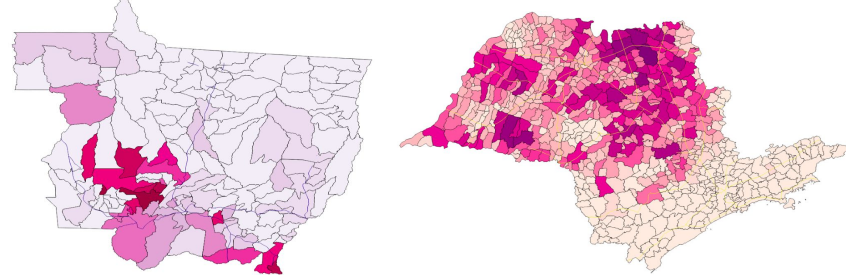

Tabela 1. Tabela Referente à área plantada, consumo de agroquímicos e embalagens utilizadas nos municípios produtores de cana-de-açúcar em São Paulo e Mato Grosso.

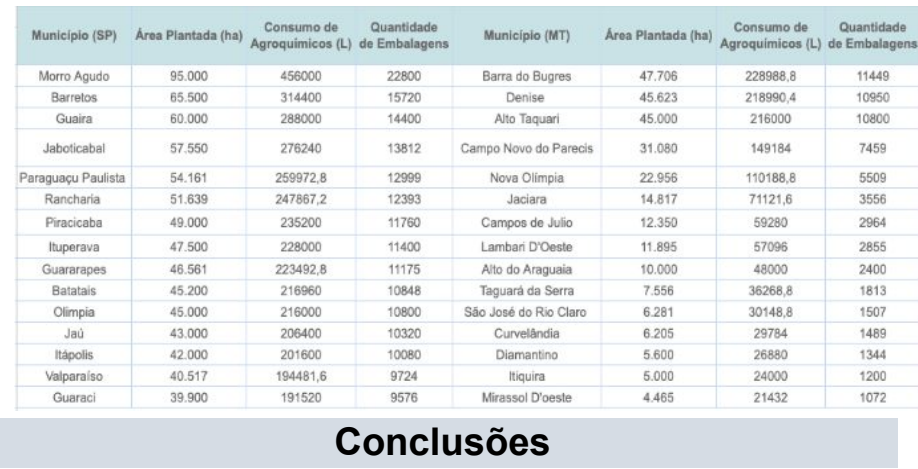

Neste contexto, percebe -se a essencialidade de recicladoras e incineradoras próximas dos locais onde há grande demanda de reciclagem de embalagens vazias de agrotóxicos.

\section{Agradecimentos}

Agradeço ao PIBIC, pela oportunidade e investimento em meu projeto, coorientação de Karina Braga Marsolla e orientação da professora Andréa Leda R. Oliveira.

SINDIVEG. Sindicato Nacional da Indústria de Produtos para Defesa Vegetal. 2019.

PIGNATI, WA. Distribuição espacial do uso de agrotóxicos no Brasil: uma ferramenta para a Vigilância em Saúde. 2017 